\title{
한국형 개발협력 모델: \\ 한국적 경험과 비교우위의 관점에서 ${ }^{1)}$
}

\author{
정 우 진 KOICA 정책연구실 연구원
}

목차
I. 연구배경
II. 한국형 모델의 개념
III. 섹터별 프로그램 분석
IV. 분석틀과 데이터베이스
V. 한국형모델의 선정
VI. 한국형 모델의 수행
VII. 결론

\section{I. 연구배경}

\section{1. 한국형 모델의 유용성과 위험성}

한국형 무상원조는 한국이 정부 주도로 단시일에 이룬 개발경험을 다른 개도국의 개발을 돕는 데 활용함으로써, 원조의 효과성과 파급력을 높이고, 제한된 자원 ${ }^{2}$ 으로도 선진국과 차별적인 협력사업 을 할 수 있다는 측면에서 많은 관심을 받으며 부각되어 왔다. 또한 한국형으로 선택된 원조 프로그 램에 선택과 집중을 함으로써 한국의 중점 섹터를 전문화시켜 향후 원조분업에 대비하는 의미도 있 다. 이는 글로벌 펀드(Global fund)와 신흥 공여국 등 점점 다양해지는 원조 수행자들로 갈수록 복 잡다단해지는 국제원조환경(Global aid architecture) 하에서 새로운 DAC 회원국으로서 자리매김 을 막 시작하는 공여국인 한국에게 매우 중요한 과제이다.

1) 본 글은 정우진 (2010) 「한국형 개발협력 모델: 한국적 경험과 비교우위의 관점에서」 보고서의 요약문임.

2) $\mathrm{DAC}$ 도너 2007년 평균 ODA $=4.70$ 백만 달러: 한국 2007년 ODA $=0.70$ 백만 달러/DAC 도너 2007년 평균 GNI 대비 $\mathrm{ODA}=0.45 \%$ : 한국 2007년 GNI대비 ODA $=0.09 \%$ 
그러나 이러한 강점에도 불구하고 과연 한국형 원조의 컨텐츠가 무엇인지, 한국의 독특한 경험이 우리와는 다른 환경에 있는 협력국에게 유용할 것인지 그리고 공여자 위주의 원조를 부추기는 것은 아닌지에 대한 우려가 존재해온 것도 사실이다. ${ }^{3)}$ 또한 한국은 신흥 공여국으로서 국제원조사회의 모범관행을 배우고 타국과의 협조로 시너지를 내는 것이 중요한데, 독자적 노선의 추구는 이를 방 해할 것이라는 비판도 존재한다. ${ }^{4)}$

\section{2. 연구의 범위와 한계}

본 연구는 이러한 한국형 원조의 장점을 극대화하고 위험성을 최소화하는 방향에서, 한국형 양자 무상원조의 개념과 범위를 우리나라 양자 무상원조의 대표적 수행기관인 한국국제협력단(Korea International Cooperation Agency, 이하 협력단)의 사업을 중심으로 정립하고자 하였다. 다음 으로 이렇게 정립된 정의에 따라서 분야별로 한국형 사업을 선정할 수 있는 분석틀(Framework)을 만들고, 이 분석틀에 따라 국제협력단의 주요 사업을 분석하여, 모델 한국형 사업이 될 수 있는 후 보 프로그램들을 세부 섹터 레벨에서 선정하였다. 그리고 잠재력이 있는 후보 프로그램들 중 가장 경쟁력 있게 선정된 최종 후보사업들을 가지고, 이를 기존 섹터 부서에서 수행했던 사업방식과는 다른 한국형 모델로 사업화하기 위한 방안을 논하였다. 그리고 한국형 원조 모델 시행을 위해서 조 직적 차원에서 개선해야 할 과제를 언급하며 결론을 맺었다.

본 연구는 「한국적 개발협력 프로그램 발전 방안 연구」(2007) 등 선행 논의를 바탕으로 하지만 기존 논의와 차별화 되게 비교우위를 지역 및 원조방식 등을 포함한 다차원적으로 개념으로 해석한 다. 기존 논의에서는 타 공여국과 한국의 중점 분야에 대한 비교분석, 협력단의 사업성과(Result) 및 역량(Capacity)에 대한 평가, 협력 대상국 및 국제적 수요분석의 미흡으로 연구를 실제 협력사 업에 활용하는데 제한이 있었다. 본 연구는 이러한 기존 연구의 부족한 점을 보완하는 동시에, 앞으 로 협력단이 강화해 갈 국별 프로그램의 관점을 보강하고자 하였다.

동 연구는 $\mathrm{KOICA}$ 의 프로젝트 사업 ${ }^{5)}$ 이 이미 한국적인 개발 경험을 원조사업에 적용시키고 있다는 가정하에 이를 중심으로 협력단이 경쟁력을 가지고 원조를 제공할 수 있는 세부 분야에 대해 실증 적인 제안을 하고자 하는 정책 보고서이다. 그러나 여기서는 한국적 개발경험에 대한 학계의 연구

3) (KOICA, 2007), 이는 선진 공여국의 기술협력이 받는 비판과도 일맥상통. Actionaid (Actionaid International, 2005) 는 공여국이 낡은(Outdated) 개발 모델을 보편적으로 적용 가능한 지식(Generic knowledge)인 것처럼 수원국에 처방하려 한다고 지적. 또한 수원국의 많은 문제들은 정치.역사적인 문제인데 비해 공여국은 자국의 전문가와 기자재를 사용한 기 술적인 문제해결에만 초점을 두고 있음을 비판.

4) (권율, 김한성, 박복영, 외, 2006), 국제협력단 내 설문조사. (경향신문, 2007)

5) 일반적 ODA 지원 사이클을 통해 지원되는 프로젝트 사업. 여기에는 동아시아 기후변화 파트너십과 같은 특별 기금이나 지원 시기가 불투명한 인도적 지원 및 긴급재난지원은 포함되지 않음 
를 고찰하거나 보다 더 원조 효과성이 있는 섹터를 계량경제적으로 분석하거나, ${ }^{6)}$ 사업부서에서 즉 시 활용 가능한 프로그램, 혹은 새로운 컨텐츠를 만들어내는 작업은 포함되지 않는다.

\section{II. 한국형 모델의 개념}

\section{1. 원조분업의 의미와 타 공여국 사례 분석}

한국의 놀라운 개발경험을 우리만의 독특한 장점을 살린 개발협력 사업으로 재탄생시키기 위해서 는 국제원조의 동향과 논의에 대한 이해가 필수적이다. 즉, 국제개발협력 분야에서는 공여국의 비 교우위를 어떻게 정의하고 있으며, 선진국들이 자국의 비교우위를 살린 개발 협력을 어떻게 실시하 고 있는지를 알아볼 필요가 있다. 이를 위해서는 먼저 공여국간의 중복 사업을 줄이고자 하는 원조 의 조화성(Harmonization) 원칙 하에 원조분업(Division of labor)의 개념을 살펴봐야 할 것이다. 원조분업은 공여국들이 한 수원국에서 관여하는 분야 및 지역을 축소시키라는 “국가 내 원조분업” 과 원조 소외국에 대한 관심을 촉구하는 “국가간 원조분업”, 그리고 “섹터적 비교우위”의 세 가지 개념으로 이루어진다. ${ }^{7)}$

원조 조화성 논의에 이어 선진국의 사례를 검토하였는데, 먼저 노르웨이(Norway)의 경험 공유 프 로그램인 “Oil for Development (OfD)" 는 한국형 모델이 성공하기 위해 필요한 요소들이 무엇인 지에 대한 교훈을 준다. 노르웨이는 효과적인 정부정책을 통해 석유와 가스에서 얻어지는 자원을 지속 가능한 개발이 되도록 관리 · 투자하고 있는데, 이러한 경험을 석유 생산 개도국과 공유하는 프로그램을 $\mathrm{OfD}$ 라 한다. ${ }^{8)}$ 이 프로그램은 석유 분야에서 국제적으로 인정받는 정부정책과 석유 섹 터에 대한 기술, 원조 관련 부처와 석유 섹터 공기관의 협력, 그리고 다양한 민간 협력기관과 국제 기구의 협조로 이루어지고 있다. 또한 석유 섹터 원조에 대한 외국기관의 평갈를 받아 원조의 성 과를 증명하고, 수원국의 지속적 요청과 함께 원조의 규모가 매년 확대되고 있다는 점도 주목할 만 하다.

6) (Dollar David \& PritcLant, Assessing Aid-What Works, What Doesn't, and Why, 1998), (Clemens Michael, Radelet Steven, Bhavnani Rikhil, Counting chickens when they hatch: The short term effect of aid on growth, 2004), (Hansen \& Tarp, 2000) 등의 페이퍼 참고.

7) (OECD, 2009b), (SchulzNils-Sjard, Division of Labour among European Donors: Allotting the Pie or Committing to Effectivenss?, 2007), (Roeske Kerstin, 2007) 참고.

8) (Norwegian Agency for Development, 2008)

9) Danish Energy Authority 
다음으로 살펴본 일본의 사례는 건설 부문 투자가 선진국 중 가장 큰 강점과 자국 경제 개발 모델 을 바탕으로 공적개발원조(Official Development Assistance: ODA)와 외국인 직접투자(Foreign Direct Investment: FDI)를 통해 개도국, 특히 아시아 국가들의 인프라 개발을 돕는 것을 비교우 위로 본다. ${ }^{10)}$ 일본은 경제개발이 빈곤감소에 미치는 영향에 대해 증명하고 ${ }^{11)}$ 시대적 적절성이 다소 떨어지는 일본의 개발 모델을 원조에 활용하는 것에 대한 비판에 대응하기 위해 연구조사에 투자하 며 환경, 인권 등과 관련한 위험이 큰 대규모 인프라 사업 실시의 가이드라인을 강화해 왔다. ${ }^{12)}$ 이 러한 일본의 사례는 일본과 원조철학과 전략이 비슷한 우리에게 시사하는 바가 크다.

그 밖에도 오스트리아(Austria)는 대규모 공여국들이 모두 농업을 비교우위로 주장하는 에티오피 아(Ethiopia)에서 유기농 농업이라는 틈새 분야와 소외된 틈새지역에 대한 지원을 통해 소규모 공 여국의 딜레마를 극복하는 전략을 보여준다. ${ }^{13)}$ 스페인은 타 공여국에서 볼 수 없는 “문화와 개발” 이라는 범분야(Cross-cutting issue)를 지원하여 새로운 섹터 개발의 가능성을 보여준다. ${ }^{14)}$ 또한 발달한 자국의 국제금융산업을 활용하여 마이크로파이낸스를 지원하는 룩셈부르크의 예에서 자국 산업과 $\mathrm{ODA}$ 의 전략적 연계성을 탐색해 볼 수 있다. ${ }^{15)}$ 더불어 협력국과 언어적 · 제도적 · 문화적 유 사성을 비교우위로 삼고 있는 포르투갈의 예는 지역적 비교우위의 측면을 보여주는 동시에 “과거” 의 경험에만 의지하는 것은 비교우위의 필요충분조건이 아니라는 것을 시사하였다. ${ }^{16)}$ 정책대화, 재 정지원 등 원조방식에 대한 비교우위에 대해 교훈을 주는 영국 ${ }^{17)}$ 과 $\mathrm{EC}$ 의 사례 ${ }^{18)}$ 도 함께 논의되었다.

\section{2. 특화된 원조의 요소}

그리고 이러한 선진 원조사회에서의 비교우위와 원조분업 개념을 통해 특화된 원조를 실시하기 위 해 필수적인 세 가지 측면, 즉 (1) 공급 (2) 과정 (3) 수요적 측면에서의 요소를 도출하였다. 어떤 원조를 공급할 것인가에 대해서는 정부 주도로 개발성과를 이뤄낸 최근의 성공적인 경험을 바탕으 로 하며, 국가의 주요 산업과 관련되어 기술적인 비교우위가 있는 원조여야 한다. 동시에 타 공여 국의 지원이 미흡한 혁신적인 틈새시장과 단순히 과거에 원조를 실시해 오던 분야 보다는 “성과”를

10) (OECD, 2004)

11) 일본은 인프라 프로젝트가 빈곤감소에 영향을 미치는지 사정하기 위해 베트남에서 사후영향평가(Impact evaluation)를 실시하였다. 베트남 하노이(Hanoi) 고속도로와 하이퐁(Hai Phong) 항구의 현대화 프로젝트의 종적 횡적 조사를 포함한 이 평가는 프로젝트 후에 FDI와 직업창출 등의 경제적 효과뿐 아니라 빈곤가구가 줄어들고 수입원이 다양화되는 등의 빈 곤감소 효과도 있었다고 보고하고 있다.

12) (OECD, 2004)

13) (OECD, 2009)

14) (OECD, 2007c)

15) (OECD, 2008)

16) (OECD, 2006a)

17) (OECD, 2006b)

18) (OECD, 2007a) 
증명한 분야를 찾아야 한다. 또한 공여국이 여러 개의 중점 분야를 가지고 있을 때 각 분야는 긴밀 히 연계되어 실시되는 것이 바람직하다. ${ }^{19)}$

어떻게 지원할 것인가 하는 과정적 측면에서는 원조방식 및 접근법과 협력 파트너 그리고 원조규모 에 대한 고려가 필요하다. 전통적 서구 공여국과 신흥 공여국의 중간에 있는 한국이 전략적인 우위 를 점하기 위해서는 두 공여국의 장점을 취하고 단점을 보완하는 원조양식(Modality)을 발전시켜 야 함을 논의하였다. 원조양식 측면에서는 선진국의 강점인 정책자문과 신흥 공여국의 강점인 인 프라 구축, 그리고 양측에서 모두 부족한 인적역량강화의 측면을 균형 있게 지원하되, 이를 프로젝 트, 봉사, 연수, 전문가, $\mathrm{NGO}$ 지원 등 개별사업 형태의 장점을 살려서 유기적인 투입요소를 활용해 야 할 것이다. 집행방식에 있어서는 빠른 속도와 적절한 비용대비 개도국에 필요한 최적의 기술로 차별화가 가능하다. 이와 함께 공여국 중심의 원조가 되는 것을 지양하기 위해서 파리선언과 아크 라 행동계획(Paris Declaration, Accra Agenda for Action: PD/AAA) 등의 국제 원조 효과성 어 젠다에 맞추어 공여국간 공식적 조화의 절차를 갖추도록 하는 프로그램형 접근법(Program-Based Approach) ${ }^{20)}$ 을 따라야 할 것이다. 협력 파트너는 공여국과 수원국의 다양한 원조 수행자들을 포함 하여 양측의 지식과 기술이 시너지를 내야 한다.

마지막으로 어느 국가에 지원을 해야 가장 성과를 볼 수 있을 것인가 하는 수요적 면에서는 선진사 례를 벤치마킹 할 수 있는 선결조건을 갖추도록 수원국이 문화, 지리적 혹은 개발조건 면에서 공여 국과 비슷하고, 그 사례에서 교훈을 얻고자 하는 수원국의 관심과 의지가 있어야 한다. 또한 타 공 여기관의 원조에서 소외된 나라와 공여국 민간기관들의 활동이 활발한 협력국을 우선적으로 고려 할 수 있다.

\section{3. 한국형 개발 협력 모델의 정의}

이러한 비교우위의 세 가지 요소를 전제로 한국형 개발협력 모델(Korean Development Cooperation Model)이 분야, 지역, 원조 실시방법의 세 가지 측면에서 정의되었다. 한국형 원조 모델은 $\mathrm{KOICA}$ 양자 무상원조 실시를 위한 전략적 모델로서, 분야, 지역, 규모, 그리고 원조 실시방

19) 예를 들어 오스트리아의 유기농 농업은 농업 분야 및 민간부문개발이라는 중점 분야와 룩셈부르크의 마이크로파이낸스 는 직업교육이라는 중점 분야와 연결되어 실시된다.

20) 프로그램 원조는 프로젝트 원조가 공여국 참가 및 통제가 높은 것에 비교, 수원국의 주인의식에 바탕을 두고 있다. 여기 서 Program-Based Approach에서의 프로그램은 공여국의 비슷한 단위 프로젝트를 모은 집합체로서의 "원조 프로그램" 이 아니라, 수원국의 자체 "개발 프로그램"을 지칭하는 것이다. 따라서 PBA는 '수원국의 개발 프로그램을 지원하기 위한 공여국들의 원조흐름을 분류하는 접근법(Approach) 혹은 프로세스(Process)'로 해석되어야 할 것이다. 공여국이 제공하 는 프로젝트, 기술협력, 예산지원 등은 PBA를 구성하는 것이 아니라 "지원" 하는 양식(Modality)으로 보아야 하며, 개별 공여국당 지원 양식은 하나일 수도 있고, 혹은 패키지적인 의미에서의 "프로그램" 형태로, 총체적으로 이루어지는 경우도 있다. 자세한 사항은 이현주 (2010), 프로그램형 접근법(PBA) 도입방안 (Forthcoming) 참고. 
법의 네 가지 측면에서 정의될 수 있다.

한국형 개발협력 모델이란, 한국 정부의 주도로 성공적인 정치 · 경제 · 사회 개발을 이끌었던 제도, 지식, 기술, 경험을 타 개도국과 공유하여 국제적 개발목표 달성에 기여하고자 하는 사업으로서, 한 국이 산업 - 기술적으로 비교우위가 있으며 타 공여국과 차별화하여 원조의 성과를 증명할 수 있는 분야의 원조이다. 원조지역은 한국과 지리 · 언어 · 문화 · 역사 혹은 기타 한국과 개발 초기 조건 면 ${ }^{21)}$ 에서 유사한 나라, 한국의 개발경험 공유에 관심과 수요가 높은 협력국, 다른 공여기관의 원조에 서 상대적으로 소외된 국가, 그리고 한국 $\mathrm{NGO}$ 나 기업 등 민간부문의 현지 활동이 활발한 나라에 우선적으로 실시된다.

규모적 측면에서 “절대적 지원규모”는 최소한 해당 원조목적코드(Creditor Reporting System Code: CRS Code) 분야에 대한 개발원조위원회(Development Assistance Committee: DAC) 회 원국의 평균 지원액 이상이 되도록 하며, 이상적으로는 주 공여국의 지원수준과 같거나 그 이상이 되도록 한다. “상대적 지원규모”는 해당 세부 분야에 가장 높은 비중으로 투자하는 공여국의 지원 비율을 참조한다.

원조 실시방법은 먼저 개별사업 형태가 통합되어 각자의 장점을 살리는 사업 요소로 유기적으로 투 입됨으로써, 정책자문과 인프라 구축 그리고 인적역량 강화의 요소가 균형을 이루고 신흥 공여국 과 선진국 원조방식의 장점을 극대화할 수 있는 “원조양식(Modality)” 으로 한다. 한국형 사업은 국 제원조규범을 준수하며 협력 대상국의 주도 하에 타 공여국과 조화되어 시행되는 것을 원칙으로 한 다. 이를 위해서는 국가지원전략(Country Assistance Strategy: CAS) ${ }^{22)}$ 을 기초로 한 국별 프로그 램의 틀에서 프로그램 원조(Program-Based Approach: PBA)의 하나인 섹터별 접근법(Sector-

21) 소득수준, 인구의 크기, 자원유무, 내륙 해안국의 지리적 여건, 내전과 같이 극단적인 정치•적 경제적 혼란 등으로 우리의 개발 초기와 비슷한 국가를 선정할 수 있다. (박복영, 채욱, 이제민, 한국 경제발전경험의 대 개도국 적용 가능성, 2007)

22) 국가지원전략(CAS) 수립 모범사례인 몽골 지원전략 수립 프로세스는 (1) 수원국의 개발전략 및 주인의식(Ownership) 현 황 분석 (2) 수원국 내 주요 공여기관의 원조분업 현황 분석 (3) 한국 ODA의 기여 가능 분야를 하위 섹터 레벨에서 분석 후 사업 후보 분석 (4) 수원국 정부 및 공여기관과 정책협의 (5) 후보사업, 예산 및 사업 관리 소요인력, 몽골 국가시스템 활용 방안, 몽골 내 원조 조화 추진안, 모니터링 및 평가 방법, 위험 관리 방안, 그리고 동 CAS 적용시 파리선언 지표별 이 행성과 예측 분석서가 포함된 3 개년 수원국 지원전략으로 구성되어 있다. 이는 세계은행과 외교통상부 자료를 바탕으로 만들어졌다. (정유아, 2009 №.2) 
Wide Approach: SWAp)을 사용한 장기적 지원을 실시한다. ${ }^{23)} \mathrm{CAS}$ 를 통해 수원국이 한국의 비 교우위 분야를 결정할 수 있게 되며, SWAp은 수원국의 개발 프로그램에 따라 타 공여국과 조화 를 이룰 수 있는 장치가 될 것이다. 사업 수행을 위한 “협력 파트너”로 한국 개발 관련 분야별 전문 성 집적을 위해 국내 관련 기관들의 협력체를 구성하고, 다자기구 및 국외 개발기관과도 협조한다. 이와 함께 한국의 경험을 각 지역에 적합하게 가공 및 적용하기 위해 현지 사무소 수원국 지방 정 부, 수원국 조달 시스템, 현지 컨설턴트, 연구기관 및 시민사회단체(Civil Society Organizations: $\mathrm{CSOs}$ )를 적극 활용한다.

\section{III. 섹터별 프로그램 분석}

\section{1. 한국과 타 공여국의 섹터별 지원 비교}

이러한 한국형 모델의 정의를 바탕으로 보다 구체적인 섹터별 사업을 선정하기 위해서는 우리나 라와 협력단이 현재 중점을 두고 있는 섹터에 대한 분석을 실시할 필요가 있다. 경제협력개발기구 (Organisation for Economic Co-operation and Development, OECD)와 KOICA 통계자료를 바탕으로 먼저 상위 섹터, 즉 사회 · 경제 - 생산 부문에서 2002-2008년까지 DAC 회원국과 한국 의 지원성향에 대해 비교한 결과 한국은 경제 부문에, $\mathrm{DAC}$ 공여국 ${ }^{24}$ 은 사회 부문, 특히 거버넌스 (Governance)나 평화구축 부문에 초점을 둔다는 것을 발견하였다. 절대 지원액 면에서 2007년을 기준으로 했을 때, 한국은 정보통신(Information and Communication Technology: ICT, IT)에 서 타 공여국 평균보다 4배가 높았고 직업훈련은 타 공여국 평균과 비슷하였으며, 나머지 부분은 대부분 적거나 비슷하였다. 상대적 비중 면에서 한국은 ICT가 전체 “섹터 지원으로 분류 가능한 원 조(Sector-allocable aid)" 에서 차지하는 비중이 타 공여국이 ICT에 투자하는 비중보다 12 배가 높 았고, 직업훈련의 경우 5 배가 높았다. 반면, 기초교육이나 인구정책 및 생식보건에 투자하는 ODA 는 각각 $\mathrm{DAC}$ 평균의 $6 \%$ 와 $1 \%$ 밖에 미치지 못하였다.

23) SWAp이란, PBA가 특정 섹터 차원에서 실시되는 것으로 이해될 수 있으며, 하위 개념으로서 SWAp은 PBA가 가지고 있 는 개념상의 특징을 모두 내포한다. PBA가 범국가적 포괄적인 개발전략을 바탕으로 한다면 SWAp은 교육, 보건 등 섹터 레벨에서 이루어지는 것으로서, SWAp은 이들 특정 분야에 관한 개발전략을 기초로 하는 것이다. 통상적으로 수원국 내 에서 SWAp이 다루는 섹터들은 빈곤감소전략(PRS)이나 국가개발전략(NDS)에서 우선 과제로 지적된 경우가 대부분이 다. DAC가 정리한 SWAp의 구성요소는 1) 수원국 주도의 명확한 섹터 정책과 전략 2) 섹터 전략을 반영한 중기 지출안 (MTEF) 3) 섹터를 지원하는 자원을 프로그래밍 할 수 있도록 하는 구조적인 합의 4) 진전 상황을 측정하고 투명성을 강화 하는 성과 모니터링 시스템 5) 모든 주요 관계자를 참여시키는 광범위한 협의 메커니즘 6) 섹터 레벨에서 원조 조정과 대 화를 위해 형식화된 수원국 주도의 프로세스 7) 보고, 예산기획, 재정관리 및 조달에 관해 조화를 추구하는 시스템을 구축 하기 위해 동의된 프로세스이다. 자세한 사항은 이현주 (2010), 프로그램형 접근법(PBA) 도입방안 (Forthcoming) 참고.

24) 호주, 오스트리아, 벨기에, 캐나다, 덴마크, 유럽위원회, 핀란드, 프랑스, 독일, 그리스, 아일랜드, 이탈리아, 일본, 룩셈 부르크, 네덜란드, 뉴질랜드, 노르웨이, 포르투갈, 스페인, 스웨덴, 스위스, 영국, 미국 


\section{KOICA와 타 공여국의 중점 분야 비교}

다음으로 $\mathrm{KOICA}$ 의 7 개 섹터별 44 개 세부 분야가 타 공여국의 중점 분야와 어떤 점에서 차별화 가 되는지 살펴보았다. $\mathrm{KOICA}$ 에서 섹터 지원으로 분류 가능한 원조 중 최상위로 지원되는 세 부 분야는 공공행정(18.20\%), 직업훈련(7.62\%), $\mathrm{ICT}(6.14 \%)$ 인 것에 비해, 타 공여국들은 고등 교육(4.20\%), HIV/AIDS 포함 성병대책(3.2\%), 공공행정(3.01\%)이 가장 높은 비중을 차지하여 $\mathrm{KOICA}$ 역시 직업훈련과 ICT에 초점을 둔다는 것을 알 수 있다. 행정제도 분야는 협력단과 타 공여 국 모두 비중 있게 지원하는데, 사업 초점에서 차이가 있었다. 협력단 행정제도(Governance) 분야 의 목표와 타겟은 경제성장전략, 민영화, 수출진흥 등을 포함하는 반면, 타 공여국은 부패나 인권, 분권화 등을 주로 다루었다.

자원분배와 관계없이 KOICA와 타 공여국이 중점 분야(Priority sector)로 “표방” 하는 분야를 분 석하면 ICT, 수송, 무역 등이 비교적 적은 공여국이 지원하는 분야라 할 수 있다. ${ }^{25)}$ 단, 협력단이 중장기 전략에서 중점 목표와 타겟으로 표방하는 사업 분야의 대부분은 일본 국제협력기구(Japan International Cooperation Agency, JICA)나 미국 국제개발처(United States Agency for International Development, USAID)와 비슷하고, ${ }^{26)}$ 원조규모 면에서도 타국 평균 이상 지원하는 부분이 드물어서 현재의 섹터별 전략만으로는 경쟁력을 갖추기 어려울 것으로 예상되었다. 또한 원 조규모는 크지 않으면서 섹터 수는 타 공여국 평균 8 개에 비해 4 개가 많은 최다 12 개 ${ }^{27}$ 를 기록하여 관심 분야를 대폭 줄여갈 필요성도 발견되었다. ${ }^{28}$

\section{KOICA의 섹터별 프로그램 분석}

상위 섹터에 대한 거시적 분석에 이어, 협력단의 7 개 섹터를 섹터 내 중점 및 한국형 경험 공유의 잠재력이 큰 세부 분야에 대한 지원비중 ${ }^{29)}$, 사업평가, 그리고 기술적 비교우위의 시각에서 $\mathrm{KOICA}$ 및 $\mathrm{OECD}$ 통계, 섹터별 평가 보고서와 기타 참고문헌을 바탕 ${ }^{30)}$ 으로 분석하였다. 이를 통해 한국형

25) (OECD, 2009c)을 참조하여 20개 DAC 공여국에 대해서 조사. ICT는 2개국이, 수송은 4 개국이 무역은 6 개국이 중점 분야 로 꼽음.

26) (USAID, 2006) (JICA, 2008), KOICA 2008-2010년 대외무상원조 중기 전략 참고

27) 다른 공여국과 비교 가능한 단위로 만들기 위해, 여러 소 분야가 합쳐져 있는 경우 이를 분리하여 계산한 결과임. 예를 들 어 산업·에너지는 수송(Transport)과 에너지(Energy) 등으로 분리하여 계산. 또한 이는 "여성" 분야가 중점 분야로 포함 되어 계산된 것임.

28) (OECD, 2009c) 별첨 4 분석 결과

29) 세부 분야당 사업총액으로 분석하였고, 사업건수나 사업연도에 대한 분석은 포함되지 않았다. 따라서 수력 발전소 건립 처럼 사업건수는 적으나 액수가 많이 드는 사업이 과대평가 될 수 있으며, 몇 해에 걸쳐 얼마나 지속적으로 투자가 이루어 져있는지를 고려하는 데는 한계가 있다.

30) 여기서의 논의는 분야별 및 형태별 평가, 프로젝트 사업 사후평가 보고서, 사업 종료평가 보고서, 국제협력단 프로젝트 사업 현황(KOICA, 2009c) 및 사업부서와의 면담 보고서(대외경제정책연구원) 등 여러 참고 문헌을 토대로 하였다. 주로 참고한 KOICA의 평가 보고서는 참고문헌에 수록. 
사업의 기초가 될 수 있는 세부 분야별로 우리나라 원조의 경쟁력을 파악하고자 하였다. 형태는 프 로젝트 사업을 위주로 하되, 연수, 봉사, $\mathrm{NGO}$ 지원 사업도 종합적으로 고려를 하였다.

교육 분야 ${ }^{31}$ 는 다른 공여국들이 고등교육에 초점을 둔 것과 달리 중등교육, 특히 직업훈련에 대한 비중이 $40 \%$ 로 매우 높았으며, 이는 산업화에 따른 기능인력 양성이라는 한국적인 경험과 우리가 가진 훈련에 대한 비교우위를 살릴 수 있는 프로그램이라 할 수 있다. 이집트(Egypt) 쇼브라 자동 차 정비센터, 카자흐스탄(Kazakhstan) 자격검정센터 구축 등 인프라 구축부터 정책지원까지 다양 한 사업의 예를 볼 수 있다.

2008년 협력단 사업 중 20\%를 차지해 가장 비중 높게 지원되었던 보건 분야는 타 공여기관들이 $\mathrm{HIV} / \mathrm{AIDS}$ 에 초점을 두는 것과 대조적으로 의료 서비스, 즉 병원건립과 의사파견에 초점을 맞추었 고, 에콰도르(Ecuador), 페루(Peru) 등에서 인정받는 모자보건센터 건립사업도 활발하였다. 그러 나 전염병 관리, 인구정책 및 행정관리 등 한국적 경험을 전수할 수 있는 부분은 모두 $3 \%$ 미만으로 지원되고 있었다.

행정제도 분야 ${ }^{32)}$ 에서는 공공행정 세부 부문이 $83.7 \%$ 로 압도적으로 높게 지원되었는데, 이중 69.44\%는 사무기기 등의 물자지원이어서 한국 경험 공유와는 크게 관련이 없었다. 반면 경제전략 자문이나 공무원 교육 등 한국의 경험 및 비교우위와 관련 있는 사업들에 대한 비중은 $6.15 \%$ 로 크 지 않았다. 또한 행정 분야에서 한국의 정책 공유는 연수생 초청의 형태로 많이 이루어지고 있었으 나 단기연수는 사업으로 평가하기 힘든 면이 있다. 알제리(Algeria)와 르완다(Rwanda) 등의 경제 개발계획 수립지원 정책자문은 제안된 정책을 시행할 수 있는 수원국의 역량 등에 대한 논의의 강 화가 보완된다면 더 효과적일 것으로 평가되었다.

통상 한국의 기술적 비교우위가 부각되고 비전통적 개발 분야인 정보통신 섹터는 $\mathrm{CRS}$ 코드의 분류 가 세분화 되어있지 않아 타 공여국과의 비교가 어렵다. IT 분야에서는 통합 시스템을 시범사업으 로 제공해 주거나 업그레이드 해주는 전자정부 지원에 높은 수요요청이 있어서 한국형 관련 사업으 로 활발히 실시되어왔다. 단, 가나(Ghana), 라오스(Laos) 등 저소득국에서는 공무원 교육 등 특정 훈련 프로그램 없이는 지속적인 시스템 유지가 어려운 점도 있었고, 중저소득국인 요르단(Jordan) 등은 더 높은 수준의 기술협력을 요구하였다.

지역개발 분야는 타국과 마찬가지로 다부문 종합농촌개발이 $22.26 \%$ 로 높게 지원되었다. 이 부분은

31) 2008 년 협력단 사업의 $14 \%$

32) 2008 년 협력단 사업의 $14 \%$ 
한국형 사업인 새마을운동이 대표적인 사업인데, 우리의 성공사례로 인해 차별화 가능성이 있는 분 야다. 그러나 전문가에 따른 성과가 다르며, 베트남(Vietnam) 등 비교적 성공적인 사례와 캄보디 아(Cambodia) 등 차후 보완 및 향상이 필요한 사례가 모두 발견되었다.

다른 $\mathrm{DAC}$ 공여국의 중점 관심 분야와 비교적 차별적인 산업 에너지 분야는 타 공여기관이 도로운 송에 높은 비중을 두는 것에 비하여, 협력단은 수력 발전소가 지원 비율 $15.66 \%$ 로 가장 높았으며, 그 밖에도 기술 연구개발, 운송정책, 전력 송배전 등 여러 사업으로 지원이 분산되어 있었다. 그 밖 에 한전 기술을 이용한 전력 송배전에 비교우위가 있어서 한국의 최신 기술을 전파할 수 있는 잠재 력을 보여준 미얀마(Myanmar), 인도네시아(Indonesia) 등의 시범 사업과 운송 사업으로 캄보디아 시엠립 우회도로 건립사업 등의 예가 있다.

환경 분야는 아직 협력단 내에서 지원비중이 미흡했고 치산녹화 등 한국적 경험을 살릴 수 있는 조 림사업 등이 중국 등을 중심으로 이루어졌으나 아직은 성과가 크게 밝혀지지 않았다. 비교적 비교 우위가 있고, 타 공여국의 지원이 낮은 폐수처리시설 지원사업은 환경 분야 지출의 $1.57 \%$ 만 차지 해 낮은 비중이라 할 수 있다.

이를 종합해 보면 협력단은 교육 및 지역개발 분야에서는 한국적 경험을 살릴 수 있는 세부 분야 에 높은 비중으로 투자한 반면, 보건이나 행정, 환경 분야에서는 한국적 경험을 살릴 수 있는 부분 에 투자가 더 이루어져야 할 것으로 보였다. 전반적으로 아직은 건축물을 짓고 기자재를 지원하는 하드웨어적인 사업비중이 큰 것은 사실이나, 소프트웨어적 지원을 강화하고 있는 긍정적인 변화가 발견되었다. ${ }^{33)}$ 또한 지속 가능성이 낮은 부서별 · 형태별 단독사업에서 지역체제의 종합적 사업으 로 변화해 가야 한다는 공감대가 넓게 형성되어 있었다. 한국형 사업의 적용에 있어서는 무엇보다 도 거의 모든 사업에 걸쳐, 수원국의 정치 · 경제 · 사회 · 환경에 대한 이해 제고 및 이들이 겪는 자 원과 능력의 제약에 대한 철저한 분석 하에서 한국의 선진제도와 기술을 공유하는 것이 핵심 과제 로 부각되었다. 이와 함께 질병관리본부 등과 같이 섹터적 전문성이 있는 공기관이나 섹터와 지역 적 지식을 겸비하면서 외국어 구사 능력이 검증된 전문가를 사업에 참여시키는 도전과제가 남아 있 다고 볼 수 있다.

33) 건축물은 높은 사업 비용이 드는데 반해, 교육 및 훈련 등 역량강화는 단위 사업 수당 많은 비용을 차지하지 않는 면이 있 으므로 이런 점을 고려해야 한다. 


\section{IV. 분석틀과 데이터베이스}

한국적 경험을 공유할 수 있는 경쟁력 있는 프로그램을 선택하여 타 공여국과 차별화시키기 위해서 는 협력단의 기존 프로그램 중 한국형 모델의 정의에 부합하는 프로그램을 선별할 필요가 있다. 본 보고서에서는 이러한 선별작업을 위한 분석틀을 제시하였다.

\section{1. 열: 분석 기준}

이 분석틀의 열(Column)은 KOICA가 경쟁력 있게 제공할 수 있는 원조를 결정하는 공급적 측면의 선정기준(Criteria)으로 (1) 한국적 경험의 내용과 관련기관, 성공요소, 보완점 및 대 개도국 적용 성 (2) 일반 산업적 기술 및 $\mathrm{ODA}$ 산업에서의 비교우위 (3) DAC 회원과 다자기관에서 집중적으로 지원하는 분야인지의 여부에 따른 차별성 ${ }^{34)}$ (4) $\mathrm{KOICA}$ 의 사업성과 및 연수사업으로 이루어져 있 다. 또한 기타 항목으로 기술은 되어있지 않으나 점수는 산정한 (5) 한국 정부의 육성 사업 부문 ${ }^{35)}$ 이 있다. 이와 함께 (1) UN의 새천년개발목표 (Millennium Development Goals, MDG) 달성이 뒤쳐지고 있는 분야 (2) 수원국의 수요 요청이 높은 분야, ${ }^{36)}$ 그리고 (3) 우리 경험의 국가 그룹별 및 지역별 적용성 ${ }^{37)}$ 을 주요한 수요적 측면의 기준으로 삼아 분석하였다.

\section{2. 행: 섹터별 프로그램}

열에는 7 개 분야 44개 세부 분야 프로그램이 각 프로그램이 속하는 섹터, 하위 섹터 및 $\mathrm{CRS}$ 코드 들과 함께 제시되어 있다. 또한 각 프로그램은 제 2장에서 논의한 한국형 프로그램의 정의에 따라 서 정책자문, 인프라 구축, 인적역량강화라는 세 가지 측면별 사업 예시로 이루어져 있다.

이러한 공급과 수요 측면의 분석 기준을 열(Column)로 하고, 협력단의 세부 분야를 행(Row)으 로 정렬한 후 이 매트릭스를 분석틀로 하여 44 개 세부 분야에 대한 각 기준별 분석이 담긴 한국

34) 2002-2007년도 사이에 DAC 양자 공여국과 다자 공여기관의 유•무상 ODA 의 합계 및 평균을 통해 구함. 특정 하위 섹터 와 가장 잘 부합되는 CRS 코드들을 먼저 파악한 후, 이 코드들에 대한 DAC공여국 평균 지원비중을 분석하여 해당 분야 에 대해 타 원조기관의 평균 지원비중이 낮으면, 차별화 점수를 높게 받는다. DAC 공여국 평균 비중은 KOICA의 7대 섹터 에 따라 분야별 비중으로 계산되었다. 예를 들어 CRS 코드 43040(다부문 농촌개발)은 주로 협력단에서 농업 분야 하에서 지원되므로 농업 분야 관련 $\mathrm{CRS}$ 코드를 모두 파악하여 여기에 지원되는 전체 지원금을 구한 후 이중 43040에 지원되는 비중을 파악하는 것이다.

35) 녹색 사업, 수자원 관련 사업

36) 수원국에 대한2010년 사업 수요조사를 바탕으로 함.

37) 국가 그룹별: 발전단계, 소득수준(LDC/LIC/MIC), 취약국(Fragile State: FS) 및 고채무국(Heavily Indebted Poor Country: $\mathrm{HIPC}$ ) 여부, 자원 유무, 인구, 지리적 여건(내륙/해안), 정치의 불안정성 등에 따른 국가 그룹별로 한국적 경험의 적용 가 능성과 원조시 고려해야 할 점에 대해 논의.

지역별: 아시아, 아프리카, 중남미, 중동, 동구 CIS 등 지역별로 한국의 경험의 적용 가능성 및 원조시 고려해야 할 점에 대해 논의. 
형 데이터베이스로 제시하였다. 그리고 이 분석 결과에 따라 각 프로그램에 대한 점수가 책정되 어 점수표로 제시되었다. 물론 이러한 정량적 분석은 주관성이 개입될 수 있고 서열 변수(Ordinal variable $)^{38)}$ 인 등 여러 이유로 해석에 있어서 주의를 요한다.

\section{V. 한국형 모델의 선정}

\section{1. 기준을 다양화한 프로그램 선정}

이렇게 산정된 점수와 분석 내용은 한국형 모델을 선정할 수 있는 기본적, 계량적 지표가 될 수 있 다. 그러나 분석 매트릭스(Matrix) 중 어떤 기준(Criteria), 즉 어떤 열(Column)을 포함시키고 각 각의 가중치는 얼마인가 하는 것은 가치적 판단을 요구하며, 이에 따라 다양한 결과가 나올 수 있 다. 이러한 논란의 소재 때문에 본 보고서에서는 다양한 시나리오를 고려하였다. 즉 (1) 수요를 포 함한 모든 기준을 종합적으로 고려하는 방법과 (2) 공여자인 한국이 경쟁력을 가지는 공급적 측면 만 고려한 방법 (3) 다른 공여국이 중점 지원하는 분야인지의 여부가 핵심적인 기준이 아니라고 가 정하고 차별화와 관련한 점수를 제외하는 방법 (4) 새천년개발목표(MDG) 목표, 타겟(Target), 지 표(Indicator)와 많이 관련된 사업에 대한 가산점을 주는 방법 (5) 현 정부가 중점을 두고자 하는 녹색사업이나 수자원 관련 산업에 가산점을 주는 방법 등 다양한 점수 책정방법이 있을 수 있다. 이 러한 5 가지 시나리오를 통해서 상위 점수를 획득한 23 개 프로그램을 우선 리스트로 만든 후, 그 중 에서도 상위 3-4위에 속하는 세부 분야로만 10개를 선정하였다. 이는 직업훈련, 전자정부, ICT 인 력 양성, 경제개발전략 수립지원, 산림보전, 상 - 하수 관리개선, 안정적 전력 공급망 확충, 종합수 자원개발, 농촌종합개발, 모자보건 ${ }^{39)}$ 이다. 이렇게 선정된 10 개의 프로그램이 실제 한국형 특화 프 로그램으로서 수행 가능한지를 탐색해 보기 위해 부서별 면담을 실시하였고, 선정된 프로그램의 장 단점이 파악되어 최종 5 개 한국형 모델 후보가 선정되었다. 최종 5 개 후보는 교육의 직업훈련, 정 보통신의 전자정부, 행정제도의 경제개발전략지원, 지역개발의 참여적 농촌종합개발, 산업 및 에너 지의 안정적 전력망 구축이다.

38) 변수간 간격이 일정한 Interval variable과는 다름.

39) 모자보건 사업은 MDG 달성과 관련하여 매우 중요하다. 그러나 한국형으로 실시할 수 있는 모자보건 사업이 명확하지 않 으므로 우리나라 경험을 근거로 상향(Bottom-up) 방식의 가족계획요원제도를 활용하여 가족계획 사업과 접목이 가능 할 것이다. 또한 우리나라의 IT기술을 "아동질병 통합관리(Integrated Management of Childhood IIIness: IMCI)" 프로그 램에 접목한 "컴퓨터 기반 아동질병 진단 프로그램(Computer-based Learning Program for the Diagnosis of Childhood Diseases: ICATT)"에 집중해 볼 수 있으며 이러한 사업 분야를 수원국에 적극 홍보할 수 있을 것이다. 


\section{2. 선정된 프로그램의 장 - 단점과 과제}

이렇게 선정된 최종 5 개 프로그램은 장 - 단점이 있다. 먼저 직업훈련 경우는 협력단 사업성과와 노 하우(Know-how)가 있고 수요요청도 높으나 독일 등 타 선진국과의 차별성에 대해서는 명확히 할 필요가 있다. 다음으로 전자정부는 우리의 최신 경험 적용이 가능하며 국가 주력사업과도 부합하나 적용이 용이한 국가가 중소득국 이상이고, 사업이 성공적으로 실시되기 위해 안정적 전력 공급이라 든가 전산화된 행정 시스템을 운영할 공무원 교육 등 포괄적으로 전제해야 할 요소가 많다. 경제개 발전략지원은 한국형 제도 및 경험 공유의 핵심이 될 수 있는 사업이다. 그러나 정책 보고서가 실제 사업과 연계되어야 하는 도전 과제와 KDI의 지식공유사업(Knowledge Sharing Program: KSP) 과의 중복 문제를 해결해야 한다. 송배전 효율성 향상 부문은 최신 기술과 산업적 비교우위를 가지 고 있고 ‘계획수립-설계-운용' 등에 이르는 협력 사업의 연계성을 보여주었다. 그러나 미국 등 다 른 공여국도 관심을 가지고 대규모로 지원하는 분야이고, IT 기술을 기반으로 하고 있기 때문에 실 질적으로 개도국에서 활용도가 낮을 수 있다. 또한 아직 협력단 내 성과가 더 축적되어야 할 필요성 이 있으며, $\mathrm{EDCF}$ 와도 연계성을 가져야 한다. 참여적 농촌종합개발사업의 경우는 개도국의 수요가 높고 전통 $\mathrm{DAC}$ 공여국의 지원이 부족한 틈새시장이며 한국의 직접 개발사례가 어필할 수 있는 소 프트웨어적인 사업이지만, 농업이 우리의 주력사업이 아니고 이 분야의 젊은 층 종사자가 적으므로 새로운 지식과 기술을 전달하는 것이 관건일 것으로 예상되었다.

이렇게 노르웨이와는 달리, 명확히 한국형 사업으로 실시할 수 있는 단 한 가지 사업을 찾는 것에는 제약이 있었으나, 경쟁력 있는 상위 1-5개의 프로그램을 한국형 모델로 '수행’하는 방안은 논의될 수 있을 것으로 보인다.

\section{VI. 한국형 모델의 수행}

\section{1. 한국형 모델 사업화 방안: 직업훈련을 예시로}

따라서 제 6장에서는 한국형 모델로 선정된 세부 분야의 사업화하는 방안을, 종합점수에서 1 위를 한 직업훈련을 예시로 설명하였다. 사업화를 위해서는 먼저 개도국이 벤치마킹 가능한 한국적인 제 도와 경험, 기술이 무엇인지 도출하는 과정이 필요하다. 직업훈련의 경우 이는 정부 주도의 기술자 격검정제도와 검정을 집행하는 정부기관, 그리고 모델 기술훈련학교일 것이다. 이러한 경험의 전 달과정에서 선진국과 차별화될 수 있는 방안은 IT라는 비교우위를 바탕으로 자격검정시험용 전산 시스템을 구축해 주거나 수요가 높고 우리의 기술과 경험을 잘 활용할 수 있는 자동차 공과나 전자 
과에 집중할 수 있을 것이다. 또한 현지에 있는 한국의 전자 및 통신 관련 대기업들의 사회적 책임 (Corporate Social Responsibility, CSR)과 연계하거나 산학협력을 하는 방법이 가능할 것이다. 이와 함께 사전조사와 산업분석을 강화하여 공과목, 기술수준, 훈련 대상 및 지역에 대한 섬세한 타 겟팅(Targeting)을 통해 특화가 가능할 것을 제시하였다.

원조 가능 지역도 미리 후보그룹의 풀(Pool)을 만들어 놓을 수 있다. 먼저 몽골(Mongol)이나 에티 오피아같이 수원국의 빈곤감소전략(Poverty Reduction Strategy Paper: PRSP), 국가개발정책 (National Development Plan: NDP) 등을 바탕으로 타 공여국의 지원 분야를 고려하여 한국의 비 교우위를 제시한 $\mathrm{CAS}$ 가 있다면 가장 먼저 참고를 해야 할 것이나, 아직 이러한 CAS 수립 전이라 면 대안적인 방법을 쓸 수 있다. 예를 들어 우리와 지역 · 문화적 유사성이 있어 비교적 쉽게 경험 을 적용할 수 있는 캄보디아, 베트남, ${ }^{40)}$ 몽골, 중국에 지원이 가능하며, 혹은 우리의 개발 당시와 초 기 조건이 비슷한국가로 자원의존여부, 소득수준, 인구, 공업화를 위한 기초적 여건 등을 충족한 국가를 ${ }^{41)}$ 고려할 수 있다. 중점 협력 대상국 중 원조 소외국이며 우리 사업에 대한 꾸준한 수요가 있다는 관점에서는 우즈베키스탄(Uzbekistan)과 카자흐스탄 등을 생각해 볼 수 있다. 이 중에서 도 한국 $\mathrm{NGO}$ 나 기업의 현지 진출이 활발하여 그들의 현지 지식(Local knowledge)이나 네트워크 (Network)를 활용할 수 있는 지역으로 더 후보국가를 좁혀갈 수 있을 것이다. 또한 이런 후보국가 그룹별로 소득수준이나 기타 특성에 따라 직업훈련사업의 초점이 달라질 것이다.

원조규모는 $\mathrm{DAC}$ 연평균 직업훈련 분야 지원금인 10.77 백만 달러 이상, 이 분야 주 공여국인 독일 의 76.73 백만 달러와 비슷하게 확대하는 방안을 제시하였다. 동시에 공여국 직업훈련이라는 원조 목적코드(11330)에 가장 높은 비중으로 지원하는 룩셈부르크(Luxembourg)의 지원비율을 참고로 직업훈련 세부 분야에 전체 $\mathrm{CRS}$ 코드별 $\mathrm{ODA}$ 지원액 중 $4.12 \%$ 이상을 할당하도록 제시하였다. ${ }^{42)}$

원조 방법은 국별 프로그램 하의SWAp 형식으로 (1) 직업자격 직업교육관련 법 제도를 보완하거나 직무표준 분석 및 노동시장 정보관리 등을 지원하는 정책 자문과 (2) 직업훈련원을 건립하고 운영 기본 계획을 수립하며 진로지도 시스템을 도입하는 인프라 구축 (3) 관련 공무원 및 현지 교사 훈 련을 지원하는 인적 역량 지원의 세 요소에 균형 있게 지원될 수 있도록 제시하였다. ${ }^{43)}$ 또한 프로젝 트, 봉사, 연수, 민간협력팀이 각자의 강점을 활용한 업무 분장을 통해서 유기적으로 이 세 가지 요

40) 베트남은 사회주의라는 상이한 정치 구조를 가진다는 면도 있음.

41) 1) 자원 의존형 국가 제외 2) 연간 소득수준이 250-2,000달러의 범위 내에 있는지의 여부 3) 인구규모에서는 2004년 현 재 인구가 100 만명 이하로 매우 작은 나라들을 제외 4) 공업화를 위한 기초적인 조건을 구비하고 있느냐의 여부 위의 네 가지 기준을 모두 충족한 사하라 이남 아프리카 국가 중 중점 및 일반 협력 대상국은 세네갈, 가나, 탄자니아, 말 리, 우간다 등이다. (박복영, 채욱, 이제민, 한국 경제발전경험의 대 개도국 적용 가능성, 2007) 참고.

42) 협력단은 현재 직업훈련 분야에 $6.14 \%$ 를 지원하고 있어 현재로도 높은 비중을 보임.

43) 현재 협력단 프로젝트도 이 세 요소를 고려하기는 하지만 인프라 구축의 비중이 훨씬 큼. 
소의 투입물(Input)을 지원하는 방안을 논의하였다. 예를 들어 봉사단은 직업훈련원의 교사를 훈련 시키는 인적역량강화에 활용될 수 있고, $\mathrm{NGO}$ 등 현지 밀착형 기관은 작은 농어촌 마을에서 자립에 필요한 단순한 기술을 가르치는 일을 할 수 있을 것이다.

이러한 한국형 사업을 시행하기 위한 국내 · 외 협력기관을 구성하여 이들이 협의체로 운영하는 한 국형 사업의 수행체계에 대해 제안하였다. 먼저 (1) 정책 및 전략을 수립하고 대규모 사업에 대해 심사를 하기 위해 $\mathrm{KOICA}$, 외교통상부, 기획재정부, 노동부, 교육과학부, 국제개발협력위원회를 포 함하여 정부운영위원회를 구성하고 (2) 산업인력관리공단, 대한상공회의소, 직업능력개발원, 노 동연구소가 집행을 담당할 수 있다. 이와 함께 (3) 협력기관으로 모델학교 및 연구기관이 될 수 있 는 한국폴리텍대학 및 한국기술교육대학교 개도국기술이전연구소와 직업훈련 분야에서 활동하는 7 개의 국내 $\mathrm{NGO}, \mathrm{ILO} / \mathrm{APSDEP}, \mathrm{APEC}, \mathrm{UNDP}, \mathrm{UNESCO}$ 등 관련 분야 국제기구, 그리고 현지 $\mathrm{CSO}$ 와 컨설턴트 연구기관 등을 제시하였으며 (4) Inwent 등 국외 평가기구가 수혜자 평가 및 사후 영향평가 등을 실시하여 수원국과 평가결과를 공유하고 (5) 해외 공관과 $\mathrm{KOICA}$ 해외 사무소가 수 원국 정부와 협조하여 사업발굴과 수요접수기능을 할 수 있다.

직업훈련을 예시로 기존 사업과 다른 형태로 진행되는 한국형 모델의 사업화를 논한 후, 최종 선정 된 다른 사업들을 한국형 모델로 발굴하기 위한 가이드라인을 단계별로 제시하였다. 이와 별도로 경제개발전략지원 분야는 $\mathrm{KDI}$ 의 $\mathrm{KSP}$ 프로그램과 $\mathrm{KOICA}$ 사업을 사업 수행방식, 공통 지원 분야 및 국가, 장 - 단점과 공통 이슈를 비교 분석한 후 통합의 필요성과 방안을 제시하였다. 통합은 협력 단의 한국형 사업 모델 안에서 경제개발전략 추진능력 강화사업의 운영체제를 만듦으로써 가능하 다. $\mathrm{PD} / \mathrm{AAA}$ 의 비구속성 원칙에 따라 집행기관이 $\mathrm{KDI}$ 에 한정되는 것은 아니나 $\mathrm{KDI}$ 는 거시경제 정책 전문기관으로 높은 경쟁력을 가지고 있으므로 실질적인 주요 사업 집행기관으로 참여하여 이 분야의 노하우(Know-how)를 공유할 수 있을 것이다.

만약 여기서 언급된 사업들이 동시다발적으로 한국형 모델화되어 운영된다면 정부 운영위는 외교 통상부, 기획재정부, $\mathrm{KOICA}$, 수출입은행으로 구성하고 각 섹터별 전문성을 가진 정부부처와 협력 기관으로 분과를 구성할 수 있을 것이다.

한국형 모델을 수행하기 위한 시행순서는 먼저 본 연구 결과물을 세미나 등을 통해 공유하고 한국 형 사업의 필요성, 개념, 세부 분야 및 사업 수, 브랜드 명에 대한 협력단 내부 공감대가 어느 정도 형성이 되면, 민관 합동 공청회 등을 개최하여 구체적인 추진전략을 세운 후, 국제개발협력위원회 의 의결을 거쳐 공식적인 한국형 $\mathrm{ODA}$ 모델을 정립해야 할 것이다. 


\section{VII. 결론}

결론으로는 한국형 모델에 대한 우려를 해소할 수 있는 방법에 대해서 정리하였다. 특히 한국의 경 험을 일방적으로 수출한다는 우려는 정책적으로는 CAS에 근거한 국별 프로그램을 실시함으로써 수원국이 우리의 비교우위를 판단할 수 있게 하고, 실행 면에서는 수원국의 재정 및 조달 시스템 활 용, 현지 사무소의 기능 강화와 현지 컨설턴트의 고용, 현지 연구기관 및 CSO와의 협력을 제도화하 는 참여적 접근법(Participatory approach) ${ }^{44)}$ 을 사용함으로써 공급자 중심의 프로그램을 지양하도 록 해야 한다. 평가에 있어서도 프로그램 참가자 평가 및 평가에 다양한 이해관계자(Stakeholder) 들의 참여, 평가 보고서를 영어와 현지어로 발간하여 수원국과 평가결과를 공유하는 등의 노력으 로 수원국 국민에 대한 책임성을 높이고 한국 제도와 기술의 지역적 적용성을 향상시켜야 할 것이 다. 또 다른 우려로 내실 없이 가시성에 집착할 것이라는 비판은 성과가 있는 분야만을 모델화한다 는 점에서 어느 정도 해소될 수 있을 것이다. 원조 수행에 있어서도 '한국적'인 것에만 머무르는 것 이 아니라 한국 이상의 것, 즉 국제 모범관행 등에 대한 학습을 통해 우리가 가진 것에 대해 끊임없 이 발전시킨다는 면에서 독자노선을 간다는 비판 역시 불식시킬 수 있을 것이다. 더불어 한국적 모 델을 특정 한국 기관이나 기업에 특혜를 주는 수단으로 사용하거나, 가시성에 초점을 맞춰 당장 국 가 브랜드 향상에 '이용'하고자 하기 보다는, 장기적이고 거시적인 시각에서 내실을 다져야 수원국 에게 실질적인 도움이 될뿐만 아니라 공여국으로서 한국의 국제적 위상을 높일 수 있을 것이다.

개발 협력 평가의 5 대 측면에서 보면 한국형 모델은, $\mathrm{CAS}$ 에 근거하여 적절성을 높이고, 한국 특유 의 속도감과 비용 절감적 집행으로 효율성을 극대화 할 수 있다. 또한 경쟁력 있는 섹터에 집중하 여, 협력기관 및 사업형태간 유기적으로 연결된 체계적 운영을 통해 효과성을 높일 수 있다. 더불어 원조크기를 늘리고, $\mathrm{PBA}$ 를 실시함으로써 파급효과를 확대하고, 현지 사무소의 현지 직원고용과 현 지 조달을 활용하여 지속 가능성을 향상시킬 수 있을 것이다.

한국형 모델은 국제사회에서 대안적 원조 모델과 그 효과성에 대한 화두를 제시할 수 있다. 새로운 $\mathrm{DAC}$ 가입국으로서 우리나라에서는 한국형 개발협력 모델을 잘 다듬고 발전시킴으로써 2011년 제 4회 서울 원조 효과성 고위급 회의시 논의를 이끌어 갈 뿐만 아니라, 서구와 신흥 공여국의 가교 역 할을 담당할 수 있을 것이다.

44) David Korten의 Process-oriented "Learner's approach"나 Willam Easterley의 "Searcher's approach" 그리고 Ellerman 의 "Doer's approach" 등은 현지 수요를 발굴하고 충족시키며, 현지 지식과 조건을 적용시키고 현지 인력을 활용하는 참 여적이고 과정 중심적인 접근법을 강조하였다. 


\section{참고 자료}

\section{1. 국내문헌}

경제정책 비서관실. (2007). "개발경험 해외전수 판매사업 활성화 방안." 경제정책 비서관실.

경향신문. (2007년 1월 25일). ODA 전문가 좌담. “경향신문”.

관계부처합동. (2007). "개발경험 공유 활성화 기본계획(안)." 국제개발협력실무위 원회.

권율, 김한성, 박복영 외. (2006). "우리나라 대외원조의 선진화 방안: 국제개발협 력 패러다임의 변화와 한국 ODA의 개혁과제." 대외경제정책연구원(KIEP).

권율, 박영호, 이종운, 황주성. (2006). "개발조사사업 확대발전방안." KOICA.

권혁주, HemmingsonAnna, 이영미. (2005). "거버넌스 관점에서 본 한국 국제개 발 협력사업: 베트남 경제제도 구축 협력사업을 중심으로.” KOICA, 글로벌 거버넌스와 사회발전 연구센터.

김은미. (2010). 한국의 공적개발 원조 현황과 국제협력: 행정학을 중심으로 (Powerpoint presentation). "한국 행정학회 제 15 회 국정포럼." 한국 행 정학회.

김진오 외. (2009). “지구촌에 새긴 KOICA의 발자국." 푸른세상.

박복영, 권율, 정성춘. (2008). "ODA 관련 국내산업의 경쟁력 분석 및 제고방안." 대외경제정책연구원(KIEP).

박복영, 채욱, 이제민. (2007). “한국 경제발전경험의 대 개도국 적용 가능성." 대외 경제정책연구원(KIEP).

박수영. (2009). “사업발굴 및 형성체제 평가연구.” KOICA.

삼성경제연구소. (2007. 5. 16 (제 604호)). 개방시대 한국농업의 선택: 농업경영. "CEO Information".

새마을운동중앙회. "Saemaul Handbook."

서상선. (2002). "한국직업훈련제도의 발자취." 대한상공회의소.

이경구. (2004). "한국에 대한 개발원조와 협력: 우리나라의 수원 규모와 분야 효과 사례 등에 관한 조사연구." KOICA.

이계우. (2009 No.4). 한국의 국제개발원조 조달시장 진출 정책. "국제개발협력".

이현주. (2009). “수원국 공공재정 및 조달 시스템 활용방안.” KOICA.

이현주. (2010). “프로그램형 접근법(PBA) 도입방안."

이현주. (2009). "KOICA 사업의 삼각협력 추진방안." KOICA. 
전승훈, 이경구, 이재홍, 손성애. (2007). “한국적 개발협력 프로그램 발전방안 연 구.” KOICA.

전승훈, 이태주, 김달현, 이태희, 전은영. (2006). “우리나라 무상원조사업의 중장 기 정책 및 전략.” $\mathrm{KOICA}$.

정기환, 김용택, 허장. (2007). “대 개도국 농촌개발 경험 전수 방안 연구." 한국농 촌경제연구원.

정유아. (2009 No.2). 한국 공적개발원조(ODA)의 ‘국가지원전략(CAS)’활용 현황과 과제. “국제개발협력”.

조성준, 홍소정. (2007). 한국형 개발원조 모델: 미니 모자보건소의 설립을 중 심으로. , 제 3회 국제개발협력 논문공모 수상 논문집 (페이지: 13-49). KOICA.

조원권, 박정호. (2005). “ICT 협력사업 추진전략."

통계청. (2009). “OECD 세계포럼의 이해." 통계청.

한국농촌경제연구원. (2005). “농업분야 협력사업 평가.” KOICA.

한국에너지자원기술기획평가원. (2009). “그린에너지 전략로드맵: 태양광, 풍력.”

한국환경정책평가연구원. (2007). “환경분야 협력사업 평가.” $\mathrm{KOICA}$.

한무영, 허옥경, 김충일, 외. (2010년 1월). 빗물저장 튜브 보급을 통한 아시아 물 빈곤 지역 식수난 해결 전략. “국제개발협력학회 정기학술회의 자료집”.

한성대학교 산학협력단. (2007). “ICT 분야 협력사업 평가.” KOICA.

해외원조단체협의회. (2007). “한국국제개발협력NGO편람."

허길행, 전승훈, 유철, 최미애. (2008). “아프리카 빈곤 대책으로서의 농촌 개발: 한 국 농촌개발 경험의 전수를 중심으로.” 한국개발전략연구소, 대외경제정책 연구원(KIEP).

홍동표, 고상원, 문성배. (2005). “2004 IT 산업 경쟁력 국제 비교 - OECD 국가 중심으로.” 정보통신정책연구원(KISDI).

\section{2. 국외문헌}

Actionaid International. (2005). "Real Aid: Making Technical Assistance Work.” Actionaid International.

AnholtSimon. (2003). “Brand New Justice.” Butterworth-Heinemann. 
Bucar, M., Marques, J. M., \& Mesic, A. (2007). Towards a Division of Labour in European Development Co-operation: Case Study. German Development Institute.

Cassen, R. (1994). Does Aid Work? New York: Oxford University Press.

Chang Ha-Joon. (2003). The East Asian Development Experience., Rethinking Development Economics. Anthem Press.

Chang Ha-Joon. (2007). “The East Asian Development Experience: The Miracle, the Crisis \& the Future." Zed Books.

CIA. (2009년 10월). “CIA Factbook”. https://www.cia.gov/library/publications/the-worldfactbook/index.html에서 검색됨

Clemens Michael, Radelet Steven, \& Bhavnani Rikhil. (2004). "Counting chickens when they hatch: The short term effect of aid on growth.” Center for Global Development .

Crola Jean-Denis. (2009). “Aid for Agriculture: Turning Promises into Reality on the Ground.” Oxfam.

DAC Evaluation Network. "Evaluation Systems and Use: a Working Tool for Peer Reviews and Assessments.” OECD.

DFID. (2008). “Annual Report.”

Dollar David, \& Pritc Lant. (1998). “Assessing Aid-What Works, What Doesn't, and Why.” World Bank.

Easterly William. (2006). “The White Man's Burden: Why the West's efforts to aid the Rest Have.” The Penguin Press New York.

EIU. (2009). "Industry Report: Telecoms and Technology - South Korea."

Endberg-Pedersen Paul. (2009년 06월 29일). Objectives and Management of Norwegian

Development Policy and Aid. "ODA Joint Workshop”.

ETF. (2009). “Uzbekistan ETF Country Plan 2009.” European Training Foundation.

Europa. (2007). "Code of Conduct on Complementarity and the Division of Labour in Development Policy."

European Commission. (2008). Communication from the Commission to the Council and the European Parliament COM(2008)409. "Environment Policy Review”.

European Commission. (2008). “DAC Division of Labour Questionnaire: The Results.” Brussels.

Feng Lu. (2009). China's Economic \& Technical Cooperation with Other Developing Countries (Powerpoint Presentation). "The 2nd International Policy Workshop on Aid Effectiveness".

Government of Japan. (2005). “Japan’s Medium-Term Policy on Official Develoment Assistance." 
Government of The Republic of Korea. (2009). “Memorandum on Korea’s Development Cooperation.”

GTZ. “GTZ's Cooperation in Technical and Vocational Education and Traning.” GTZ.

Hansen, H., \& Tarp, F. (2000). Aid and Growth Regression. Centre for Research in Economic Development and International Trade.

Jerve Morten Alf, \& Selbervik Hilde. (2009). “Self-Interest and Global Responsibility: Aid Politics of South Korea and India in the Making." CHR. Michelsen Institute.

JICA. (2008). “ODA White Paper: Japan's International Cooperation.”

Joo Dong-Joo. (2009). “Republic of Korea: Transforming from Recipient to Donor (Powerpoint presentation)." The 2nd International Policy Workshop on Aid Effectiveness.

Jung Woojin. (2007). Analysis of Impact Evaluation Systems for Exim Bank Development Assistance Loans. Harvard Kennedy School.

KOICA. (2009). “1992-2008 국제협력단 프로젝트사업 현황.” KOICA.

KOICA. (2009a). “개발조사사업 형태별 평가결과 보고서.” KOICA.

KOICA. (2009b). "개발조사사업 활용실태.” KOICA.

KOICA. (2007). “과테말라 기술교육훈련원 건립사업.” KOICA.

KOICA. (2008). “교육분야 지원사업 분야별 평가 보고서.”

KOICA. (2009c). “국제협력단 프로젝트 사업현황.” KOICA.

KOICA. (2008a). "라오스 전자정부 구축 지원사업 사후평가 보고서.” KOICA.

KOICA. (2008b). "미얀마 IT 개발 마스터플랜 지원사업 사후평가 보고서.” KOICA.

KOICA. (2008c). “베트남 마약통제 행정현대화사업 사후평가 보고서.” KOICA.

KOICA. (2008d). “베트남 IT 입법 지원사업 사후평가 보고서.” KOICA.

KOICA. (2008e). “보건의료분야 분야별 평가 보고서.” KOICA.

KOICA. (2007a). “연수과정 종료평가.” KOICA.

KOICA. (2007b). “요르단 2개 정부부처 정보화 지원사업 사후평가 보고서.” KOICA.

KOICA. (2007c). “정보통신분야 4개 사업 위탁평가 보고서.” KOICA.

KOICA. (2009c). “제 3회 ODA 서울 국제컨퍼런스 결과 보고서.”

KOICA. (2008g). “캄보디아 상품서비스 무역능력 배양사업 사후평가 보고서.” KOICA.

KOICA. (2007d). “캄보디아 타목저수지 복구 지원 사업 사후평가 보고서.” KOICA.

KOICA. (2008h). “필리핀 미곡종합처리장 건립사업 사후평가 보고서.” KOICA.

KOICA. (2007). “한-라오스 직업훈련원 건립사업 평가.” KOICA.

KOICA. (2008i). “해외봉사단 파견사업 종합평가 보고서.” KOICA.

KOICA. (2008). "ESCAP 새마을운동 1차 시범사업 사후평가 보고서.” KOICA. 
KOICA. (2008f). “KOICA 연수과정 종료평가.” KOICA.

KOICA. "Making a Better World Together.” KOICA.

KOICA. (2007). "ODA 국제컨퍼런스 결과 보고서."

KOICA, KHIDI(한국보건산업진흥원). (2005). “한국 국제협력단 보건의료 협력사업 평가.” KOICA.

Korten David. (1980). Community Organization and Rural Development: A Learning. "Public Administration Review Vol. 40(5).”, Pp. 480-511.

Kusano Atsushi. (아츠시 쿠사노). (2006). “해체(解體): 국제협력은행의 정치학.” 동양경 제신보사.

Lancaster Carol. (1999). Aid effectiveness in Africa: The unfinished agenda. "Journal of African Economies", 487-503.

Leipziger Danny, \& Kihwan Kim. (2000). Korea: A Case of Government-Led Development. , Lessons from East Asia. The University of Michigna Press.

Lim Kyungbim. “Korea's National Technical Qualification Management System: Current State and Task Ahead."

Ministry of Foreign Affairs, OECD. (2008). Development Co-operation of the Republic of Korea: DAC Special Review. Ministry of Foreign Affairs, OECD.

Munyi N .Elijah. (2008). Exporting 'Saemaul' Movement. “Korea Times”.

National Council of Saemaul Undong Movement in Korea. (2003). Saemaul Undong Handbook.

Norwegian Agency for Development. (2008). "Oil for Development Annual Report." NORAD.

OECD. (2008b). "2008 Survey on Monitoring the Paris Declaration: Making Aid More Effective By 2010.” OECD.

OECD. (2009e). “Aid Effectiveness: A Progress Report On Implementing the Paris Declaration." OECD.

OECD. (2006). “Analysis of Aid for Basic Social Services 1995-2004.” OECD.

OECD. (2009). “Austria DAC Peer Review.” OECD.

OECD DCD/DAC. (2007). “DAC Statistical Reporting Directives.” OECD.

OECD. (2007d). “Denmark Peer Review.” OECD.

OECD. (2009a). Development Co-operation Report 2009. “OECD Journal on Development".

OECD. (2007a). “EC DAC Peer Review.” OECD.

OECD. (2007b). “Ensuring Fragile States Are Not Left Behind.” OECD.

OECD. (2006d). “Harmonising Donor Practices for Effective Aid Deliverty.” OECD. 
OECD. (2009b). “International Good Practice Principles for Country-Led Division of Labor and Complementarity." OECD.

OECD. (2004). “Japan DAC Peer Review.” OECD.

OECD. (2008). “Luxembourg DAC Peer Review.” OECD.

OECD. (2009c). “Managing Aid: Practices of DAC Member Countries.” OECD.

OECD. (2008a). “Measuring Aid to Health.” OECD.

OECD. (2009d). "Measuring Aid to Water Supply and Sanitation."

OECD. (2006a). "Portugal DAC Peer Review.” OECD.

OECD. (2007c). “Spain DAC Peer Review.” OECD.

OECD. (2000d). “Sweden DAC Peer Review.” OECD.

OECD. (2006b). “UK DAC Peer Review.” OECD.

OECD. (2006c). “Working towards Good Practice.” OECD.

Oyejide Ademola. (2004). “Trade Liberalization, Regional Integration, and African Development in the Context of Structural Adjustment.” IDRC.

Rihani Samir. (2002). “Complex Systems Theory and Development Practice: Understanding Nonlinear.” Zed Books London \& New York.

Roeske Kerstin. (2007). The Code of Conduct for a Better Division of Labor in the Development Policy-Is it a real milestone? "Brussels Focus".

Rowlands Dane. (2008). “Emerging Donors in International Development Assistance.” International Development Research Center (IDRC).

Schulz Nils-Sjard. (2007). Division of Labour among European Donors: Allotting the Pie or Committing to Effectivenss? "FRIDE Comments".

Smith F. James. (2009년 6월 14일). US Faces Global Health Aid Dilemma. “Boston Globe”.

Stiglitz Joseph. (1996년 8월). Some Lessons from the East Asian Miracle. “The World Bank Reseach Observer”, 페이지: 157-77.

UNCTAD. (1996). “Trade and Development Report.” UNCTAD.

UNDP. (2008). "Batken Area Based Development Programm: Draft Brief Update for the Korea Policy Consultation Meeting.” UNDP.

UNESCO. (2008). "Education for All Global Monitoring Report.” UNESCO.

United Nations. (2008). “E-Government Survey: From E-Government to Connected Government.” United Nations.

United Nations. (2008b). “The Millennium Development Goals Report.” United Nations.

USAID. (2006). “USAID Primer: What We Do and How We Do It.” USAID.

Varughese George. (2009). Emerging Era of Development Cooperation: The Role of India. The 2nd International Policy Workshop on Aid Effectiveness. 
Workshop Steering Committee of the 2nd Policy Workshop on Aid Effectiveness. (November 2009). “Co-Chair Summary." The 2nd International Policy Workshop on Aid Effectiveness in Seoul.

World Economic Forum. (2008). “Global Competitiveness Report.” World Economic Forum.

World Economic Forum. (2009). “Global Competitiveness Report 2009-2010.” World Economic Forum. 